\title{
ANALISIS EFEKTIVITAS DAN KONTRIBUSI PAJAK KENDARAAN BERMOTOR TERHADAP PENERIMAAN PENDAPATAN ASLI DAERAH DI PROVINSI MALUKU UTARA
}

\author{
Oleh : \\ Hasannudin \\ Heince R. N. Wokas \\ Fakultas Ekonomi dan Bisnis \\ Program Pendidikan Profesi Akuntansi \\ Universitas Sam Ratulangi Manado \\ Email : Hasannudin2h@gmail.com
}

\begin{abstract}
ABSTRAK
Reformasi di bidang perpajakan dilakukan oleh pemerintah pusat, guna melaksanakan otonomi daerah, yakni dengan membagi sumber penerimaan negara berupa pajak pusat dan pajak daerah. Pajak kendaraan bermotor merupakan salah satu jenis pajak daerah yang sangat potensial dalam meningkatkan penerimaan daerah bagi provinsi maluku utara sebagai provinsi kepulauan, dimana moda transportasi utama dalam menghubungkan seluruh wilayah diprovinsi maluku utara adalah mengunakan kendaraan bermotor, baik yang dioperasikan didarat maupun dilaut. Tujuan dari penelitian ini adalah untuk mengetahui efektivitas dan kontribusi penerimaan pajak kendaraan bermotor terhadap pendapatan asli daerah (PAD). Data yang telah diolah kemudian dianalisis dengan menggunakan analisis deskriptif kualitatif. Hasil penelitian menunjukan bahwa penerimaan pajak kendaraan bermotor diprovinsi maluku utara efektif. Sementara kontribusi pajak kendaraan bermotor terhadap penerimaan PAD adalah kurang baik. Disisi lain efektivitas dan kontribusi pajak kendaraan bermotor terhadap PAD menunjukan tren yang menurun. Hal ini menunjukan bahwa dinas pendapatan dan pengelolaan aset daerah provinsi maluku utara sudah baik dalam mengelola penerimaan pajak kendaraan bermotor namun belum serius dalam mengoptimalkan potensi penerimaan pajaknya.
\end{abstract}

Kata kunci : Otonomi daerah, Pajak Pusat, Pajak Daerah, Pajak Kendaraan bermotor, Kontribusi, Efektivitas.

\begin{abstract}
Taxation reforms carried out by the central government, in order to implement regional autonomy, namely the sharing of resources in the form of central tax revenues and local taxes. Motor vehicle tax is one type of tax potential in the area of revenue generation for the province as a province of North Maluku islands, where the main mode of transportation in connecting the entire region of North Maluku is diprovinsi motor vehicle, both on land and at sea operated. The purpose of this study was to examine the effectiveness and contribution of the motor vehicle tax revenue to local revenues. The data have been processed and analyzed using qualitative descriptive analysis. The results showed that the motor vehicle tax revenue diprovinsi North Maluku effective. While the contribution of the motor vehicle tax revenue receipts are less good. On the other hand the effectiveness and contribution of the motor vehicle tax revenue showed a declining trend. This shows that the revenue department and the asset management area, North Maluku province has been good in managing motor vehicle tax revenue but not serious in optimizing the potential tax revenue.
\end{abstract}

Keywords: Fiscal Decentralization, Central Tax, Local Tax. Motor vehicles tax, Contribution, Effectiveness. 


\section{PENDAHULUAN}

\section{Latar Belakang}

Pajak adalah kontribusi wajib kepada negara yang terutang oleh orang pribadi atau badan yang bersifat memaksa berdasarkan undang-undang, dengan tidak mendapatkan imbalan secara langsung yang digunakan untuk keperluan negara bagi sebesar-besarnya kemakmuran rakyat (UU No.28 tahun 2007 tentang KUP). Di Indonesia, Pajak merupakan sumber penerimaan negara yang sangat besar kontribusinya dalam membiayai kebutuhan belanja negara dan pembangunan nasional. Dimana hal tersebut tercermin dalam Anggaran Pendapatan dan Belanja Negara (APBN).

Otonomi daerah yang terjadi pada tahun 1999 yang ditandai dengan dikeluarkannya undangundang No 22 tahun 1999 tentang pemerintah daerah yang terakhir direvisi dengan undang-undang No 12 tahun 2008, dan undang-undang No. 25 tahun 1999 tentang hubungan perimbangan keuangan antara pemerintah pusat dan pemerintah daerah, yang terakhir direvisi dengan undang-undang no 33 tahun 2004. membawa dampak terhadap reformasi dibidang perpajakan yakni memberikan perubahan terhadap sistem pengumutan pajak, yakni pajak yang dipungut oleh pemerintah pusat atau disebut pajak pusat dan pajak yang dipungut oleh pemerintah daerah atau pajak daerah. pajak pusat terdiri dari Pajak pertambahan nilai (PPn), pajak penjualan barang mewah ( $\mathrm{PPnBm})$ pajak penghasilan $(\mathrm{PPh}$,) pajak migas, PBB atas perkebunan, kehutanan, dan pertambangan, dan lain sebagainya.

Sementara Pajak daerah terbagi atas pajak provinsi yang terdiri atas : pajak kendaraan bermotor, bea balik nama atas kendraan bermotor, pajak bahan bakar atas kendaraan bermotor, pajak air permukaan, dan pajak rokok. Dan Pajak Kabupaten/kota yang terdiri atas : pajak hotel, pajak hiburan, pajak restoran, pajak reklame, pajak parkir, pajak mineral bukan logam dan lain-lain, yang berguna dalam menunjang penerimaan pendapatan asli daerah.

Setiap daerah otonom dalam hal ini provinsi maupun kabupaten/kota diindonesia, memiliki sumber daya alam dan potensi ekonomi yang bervariasi, sehingga jika dimanfaatkan dengan optimal maka akan dapat memberikan kontribusi yang signifikan bagi penerimaan pendapatan asli daerah, yang pada gilirannya akan memberikan manfaat dalam pembangunan daerah.

Sebagai provinsi kepulauan, maluku utara oleh peneliti dinilai memiliki potensi penerimaan pajak yang begitu baik salah satunya yakni, pajak atas kendaraan bermotor, dimana setiap daerah diprovinsi maluku utara, dihubungkan melalui moda transportasi laut. Menurut data dari ditjen perhubungan kementrian perhubungan dalam buku profil dirjen perhubungan darat 2013 (www.ditjenhubdat.go.id), mencatat bahwa jumlah angkutan laut dimaluku utara pada tahun 2012 adalah sebesar 381 unit meningkat menjadi $13 \%$ atau sebesar 431 unit kapal dan angkutan laut sejenisnya, sementara badan pusat statistik dan kepolisian republik indonesia dalam buku profil dirjen perhubungan darat 2013 (www.ditjenhubdat.go.id), mencatat bahwa jumlah kendaraan bermotor di provinsi maluku utara tahun 2012 adalah sebesar 61.207 meningkat menjadi 11\% atau sebesar 67.445 pada tahun2013. Serta keberadaan sejumlah alat-alat berat pada perusahaan pertambangan yang ada diprovinsi maluku utara adalah merupakan sebuah potensi penerimaan pajak yang dapat memberikan kontribusi bagi pendapatan asli daerah provinsi maluku utara bila dapat dimanfaatkan secara efektif. berdasarkan beberapa alasan yang telah dikemukan diatas maka peneliti ingin melakukan penelitian tentang analisis efektivitas dan kontribusi penerimaan pajak atas kendaraan bermotor terhadap pendapatan asli daerah diprovinsi maluku utara, guna mengupas lebih lanjut seberapa efektif dan besarnya kontribusi pajak atas kendaraan bermotor terhadap pendapatan asli daerah diprovinsi maluku utara.

\section{Tujuan Penelitian}

1. Untuk mengetahui bagaimana tingkat efektifitas pemungutan pajak kendaraan bermotor terhadap penerimaan pendapatan asli daerah (PAD) pada pemerintah daerah Provinsi Maluku Utara pada tahun 2009-2013.

2. Untuk mengetahui bagaimana kontribusi pemungutan pajak kendaraan bermotor terhadap penerimaan pendapatan asli daerah (PAD) pada pemerintah daerah provinsi maluku utara pada tahun 2009-2013. 


\section{TINJAUAN PUSTAKA}

\section{Kajian Teori}

Menurut Teori Asuransi dalam Mardiasmo (2008:3) menyebutkan bahwa negara melindungi keselamatan jiwa, harta benda, dan hak-hak rakyatnya. Oleh karena itu rakyat harus membayar pajak yang diibaratkan sebagai suatu premi asuransi karena memperoleh jaminan perlindungan tersebut.

\section{Defenisi Pajak}

Menurut Soemitro dalam Mardiasmo (2008:1), pajak adalah iuran rakyat kepada kas negara berdasarkan undang-undang (yang dapat dipaksakan) dengan tiada mendapat jasa timbal (kontraprestasi) yang langsung dapat ditunjukan dan yang digunakan untuk membayar pengeluaran Umum.

\section{Pajak Daerah}

Menurut Resmi (2009:9) Pajak daerah adalah pajak yang dipungut oleh pemerintah daerah baik daerah tingkat I (Pajak Provinsi) maupun pajak daerah tingkat II (Pajak Kabupaten/Kota) dan digunakan untuk membiayai rumah tangga daerah masing-masing.

\section{Defensi Pajak atas Kendaraan Bermotor}

Menurut UU No 28 Tahun 2009 tentang Pajak \& Retribusi Daerah, Pajak Kendaraan Bermotor adalah pajak atas kepemilikan dan/atau penguasaan kendaraan bermotor. Kendaraan Bermotor adalah semua kendaraan beroda beserta gandengannya yang digunakan di semua jenis jalan darat, dan digerakkan oleh peralatan teknik berupa motor atau peralatan lainnya yang berfungsi untuk mengubah suatu sumber daya energi tertentu menjadi tenaga gerak kendaraan bermotor yang bersangkutan, termasuk alat-alat berat dan alat-alat besar yang dalam operasinya menggunakan roda dan motor dan tidak melekat secara permanen serta kendaraan bermotor yang dioperasikan di air.

\section{Objek Pajak Kendaraan Bermotor}

Objek pajak atas kendaraan bermotor adalah kepemilikan dan/atau penguasaan kendaraan bermotor. Termasuk dalam pengertian kendaraan bermotor beroda beserta gandengannya, yang dioperasikan disemua jenis jalan darat dan kendaraan bermotor yang dioperasikan di air dengan ukuran isi kotor GT 5 (lima Gross Tonnage) sampai dengan GT 7. (Tujuh Gross Tonnage).

\section{Subjek Pajak Kendaraan Bermotor}

Subjek Pajak atas Kendaraan Bermotor adalah (Pasal 4 Undang-undang No 28 tahun 2009 tentang Pajak dan Retribusi Daerah) :

a) Subjek Pajak Kendaraan Bermotor adalah orang pribadi atau Badan yang memiliki dan/atau menguasai Kendaraan Bermotor.

b) Wajib Pajak Kendaraan Bermotor adalah orang pribadi atau Badan yang memiliki Kendaraan Bermotor.

c) Dalam hal Wajib Pajak Badan, kewajiban perpajakannya diwakili oleh pengurus atau kuasa Badan tersebut.

\section{Dasar Pengenaan Pajak Kendaraan Bermotor}

Dasar pengenaan Pajak Kendaraan Bermotor adalah hasil perkalian dari 2 (dua) unsur pokok (Pasal 5 Undang-undang No 28 tahun 2009 tentang Pajak dan Retribusi Daerah) :

1. Nilai Jual Kendaraan Bermotor; dan

2. bobot yang mencerminkan secara relatif tingkat kerusakan jalan dan/atau pencemaran lingkungan akibat penggunaan Kendaraan Bermotor.

Berdasarkan Peraturan Daerah Provinsi Maluku Utara No 1 tahun 2012 tentang pajak daerah, pasal 7 dan 8 menyebutkan bahwa besarnya pokok pajak kendaraan bermotor yang terutang dihitung dengan cara mengalikan tarif pajak kendaraan bermotor dengan 2 unsur pokok sebagaimana yang diatur dalam pasal Undang-undang No 28 tahun 2009. Tarif kendaraan bermotor sebagaimana yang dimaksud dalam pasal 7 perda no 1 tahun 2012 adalah : 
1. Untuk kepemilikan kendaraan bermotor pertama sebesar 1,5\% (satu koma lima persen),

2. Untuk kepemilikan kendaraan bermotor pertama sebesar $5 \%$ (lima persen),

3. Kendaraan bermotor angkutan umum, ambulans, pemadam kebakaran, kendaraaan bermotor milik badan sosial, keagamaan, Pemerintah/TNI/POLRI, Pemerintah Daerah ditetapkan sebesar $1 \%$

4. Tarif pajak kendaraan bermotor alat-alat berat dan alat-alat besar ditetapkan sebesar $0,2 \%$.

Pengertian Efektivitas

Menurut Mardiasmo (2009:134) efektivitas adalah ukuran berhasil tidaknya suatu organisasi dalam mencapai tujuannya. Apabila suatu organisasi berhasil mencapai tujuan, maka organisasi tersebut dapat dikatakan telah berjalan dengan efektif.

\section{Pengertian Kontribusi}

Menurut Kamus ekonomi (T Guritno 1997:76) kontribusi adalah sesuatu yang diberikan bersama-sama dengan pihak lain untuk tujuan biaya atau kerugian tertentu atau bersama. Sehingga kontribusi yang dimaksud dapat diartikan sebagai sumbangan yang diberikan oleh pendapatan pajak atas kendaraan bermotor terhadap pendapatan asli daerah.

\section{Pendapatan Asli Daerah}

Menurut Halim (2007:96), Pendapatan Asli Daerah merupakan semua penerimaan yang berasal dari sumber ekonomi asli daerah. kelompok PAD dipisahkan menjadi empat jenis pendapatan, yaitu; Pajak Daerah, Retribusi Daerah, Hasil Pengelolaan kekayaan milik daerah yang dipisahkan, dan lainlain PAD yang sah.

\section{Penelitian Terdahulu}

Menurut Adelina (2012) dalam penelitiannya yang menganalisis efektifitas dan kontribusi Pajak Bumi dan Bangunan (PBB) terhadap pendapatan daerah dikabupaten gresik. Hasil penelitiannya menunjukan bahwa tingkat efektifitas penerimaan pajak bumi dan bangunan tahun 2007-2011 dikatakan sangat efektif dengan presentase lebih dari 100\%, sementara tingkat kontribusi pajak bumi dan bangunan tahun 2007-2011 dikatakan sangat kurang dengan persentase kurang dari 10\%.

Penelitian yang dilakukan oleh Tarigan (2013) dengan judul analisis efektifitas dan kontribusi PBB terhadap Penerimaan Pajak di KPP Pratama Kota Manado. Hasil penelitiannya menunjukan bahwa pajak tingkat kinerja kantor pelayanan pajak pratama manado efektif, bahkan ada beberapa tahun yang sangat efektif, begitu juga dengan kontribusinya.

\section{METODOLOGI PENELITIAN}

\section{Jenis Penelitian}

Penelitian ini merupakan penelitian deskriptif. Menurut Sugiono (2008:5) Penelitian deskriptif adalah penelitian yang dilakukan untuk mengetahui nilai variabel mandiri, baik suatu variabel atau lebih (independen) tanpa membuat perbandingan, atau menghubungkan dengan variabel yang lain.

\section{Tempat \& Waktu Penelitian}

Penelitian ini dilaksanakan pada Dinas Pendapatan dan Pengelolaan Aset Daerah Provinsi Maluku Utara pada bulan Mei 2014 hingga selesai.

\section{Jenis dan Sumber Data}

Adapun jenis dan sumber data dalam penelitian ini :

a) Data Primer

yaitu data yang diperoleh peneliti melalui wawancara secara langsung ke objek penelitian dalam hal ini melakukan wawancara ke pihak Dinas Pendapatan dan Aset Daerah Provinsi Maluku Utara.

b) Data Sekunder

yaitu data target dan realisasi Penerimaan Pajak, peraturan daerah tentang pajak atas kendaraan bermotor dan buku laporan capaian kinerja SKPD dinas Pendapatan dan pengelolaan aset daerah.

\section{Teknik Pengumpulan data}

Teknik Pengumpulan data yang dilakukan dalam penelitian ini yaitu :

a) Wawancara 
Menurut Esterberg dalam Sugiono (2008:72) wawancara adalah merupakan pertemuan dua orang untuk bertukar informasi dan ide melalui tanya jawab, sehingga dapat dikontruksikan makna dalam suatu topik tertentu. Wawancara yang dilakukan dalam hal ini yaitu pada pihak Dinas Pendapatan Pengelolaan dan Aset Daerah Provinsi Maluku Utara.

b) Dokumen

Menurut Sugiono (2008:82) dokumen merupakan catatan peristiwa yang sudah berlalu. Dokumen bisa berbentuk tulisan, gambar, atau karya-karya monumental dari seseorang. Dokumen yang dimaksud dalam penelitian ini adalah buku laporan Capaian kinerja SKPD dinas Pendapatan pengelolaan dan aset daerah.

\section{Metode Analisis Data}

Metode Analisis data yang digunakan dalam penelitian ini adalah menggunakan metode analisis deskriptif kualitatif, analisis deskriptif kualitatif adalah analisis yang diwujudkan dengan cara menggambarkan kenyataan atau keadaan-keadaan atas suatu objek dalam bentuk uraian kalimat berdasarkan keterangan-keterangan dari pihak-pihak yang berhubungan langsung dengan penelitian ini. Hasil analisis tersebut kemudian diinterpretasikan guna memberikan gambaran yang jelas terhadap permasalahan yang diajukan (Tarigan, 2013).

\section{Defenisi dan Pengukuran Variabel Operasional}

1. Analisis efektifitas.

Menurut Mardiasmo (2009:134) efektivitas adalah ukuran berhasil tidaknya suatu organisasi dalam mencapai tujuannya. Apabila suatu organisasi berhasil mencapai tujuan, maka organisasi tersebut dapat dikatakan telah berjalan dengan efektif. jadi untuk menganlisis efektifitas dari Pajak atas kendaraan bermotor maka peneliti menggunakan rumus yang telah peneiliti kembangkan dari penelitian sebelumnya yang dilakukan oleh Adelina (2012) dengan rumus sebagai berikut:

Menjadi :

$$
\text { Efektivitas } P B B=\frac{\text { Realiasasi Penerimaan } P B B}{\text { Target } P B B} \times 100 \%
$$

$$
\text { Efektivitas } P K B=\frac{\text { Realisasi Penerimaan } P K B}{\text { Target } P K B} \times 100 \%
$$

Guna untuk mengukur tingkat efektivitas maka digunakan indikator pada tabel 3.1 dibawah ini :

Tabel 3.1

Interpretasi nilai efektivitas

\begin{tabular}{|c|c|}
\hline Persentase & Kriteria \\
\hline$>100 \%$ & Sangat efektif \\
$90-100 \%$ & Efektif \\
$80-90 \%$ & Cukup \\
$60-80 \%$ & Kurang efektif \\
$<60 \%$ & Tidak efektif \\
\hline
\end{tabular}

Sumber :Depdagri, Kepmendagri No.690.900.327 (Rima Adelina, 2012)

\section{Analisis Kontribusi}

Menurut Kamus ekonomi (T Guritno 1997:76) kontribusi adalah sesuatu yang diberikan bersama-sama dengan pihak lain untuk tujuan biaya atau kerugian tertentu atau bersama. Sehingga kontribusi yang dimaksud dapat diartikan sebagai sumbangan yang diberikan oleh pendapatan pajak atas kendaraan bermotor terhadap pendapatan asli daerah. untuk mengetahui kontribusi pajak atas kendaraan bermotor terhadap Pendapatan Asli Daerah, digunakan rumus sebagai berikut :

$$
\text { Kontibusi PKB }=\frac{\text { Realisasi } P K B}{\text { Realisasi Penerimaan PAD }} \times 100 \%
$$


Tabel 3.2 dibawah ini akan menggambarkan indikator dalam menilai kontribusi pajak kendaraan bermotor terhadap Pendapatan Asli Daerah.

Tabel 3.2

Klasifikasi kriteria kontribusi

\begin{tabular}{|c|c|}
\hline Persentase & Kriteria \\
\hline $0,00 \%-10 \%$ & Sangat kurang \\
$10,10 \%-20 \%$ & Kurang \\
$20,10 \%-30 \%$ & Sedang \\
$30,10 \%-40 \%$ & Cukup Baik \\
$40,10 \%-50 \%$ & Baik \\
Diatas $50 \%$ & Sangat Baik \\
\hline
\end{tabular}

Sumber : Depdagri, Kepmendagri No.690.900.327 (Velayati Dkk, 2013)

\section{HASIL PENELITIAN DAN PEMBAHASAN}

\section{Gambaran Umum Objek Penelitian}

Objek penelitian dalam penelitian ini adalah Pajak atas kendaraan bermotor, yang dikelola oleh Dinas Pendapatan dan Pengelolaan Aset Daerah Provinsi Maluku Utara, dengan membawahi 9 UPTD SAMSAT yang tersebar di 7 enam kabupaten dan 2 kota madya, yakni : Kabupaten Halmahera barat, Halmahera Tengah, Kota Tidore Kepulauan, Halmahera Timur, Kota Ternate, Halmahera Timur, Halmahera Selatan, Kepulauan sula, dan Kabupaten Pulau Morotai, yang bertanggungjawab dalam melakukan pengumutan atas pajak kendaraan bermotor.

\section{Hasil Penelitian}

\section{Efektivitas Penerimaan Pajak Kendaraan Bermotor}

Tabel 4.1 dibawah ini akan menggambarkan efektivitas penerimaan pajak kendaraan bermotor.

Tabel 4.1

Target dan Realisasi Penerimaan Pajak atas kendaraan bermotor Pemerintah Daerah Provinsi Maluku Utara Tahun 2009-2013

\begin{tabular}{|c|c|c|c|c|}
\hline Tahun & Target (Rp) & Realisasi (Rp) & Persentase & Kriteria \\
\hline 2009 & 11.512 .200 .000 & 12.445 .271 .470 & $108,10 \%$ & Sangat efektif \\
\hline 2010 & 12.694 .194 .755 & 13.012 .917 .658 & $102,51 \%$ & Sangat efektif \\
\hline 2011 & 16.181 .204 .891 & 16.181.204.891 & $100 \%$ & Efektif \\
\hline 2012 & 22.005 .704 .000 & 19.089 .343 .202 & $86,74 \%$ & Cukup \\
\hline 2013 & 40.311 .361 .000 & 23.126 .977 .023 & $57,37 \%$ & Kurang Efektif \\
\hline \multicolumn{3}{|c|}{ Rata- rata } & $90,94 \%$ & Efektif \\
\hline
\end{tabular}

Tabel 4.1 diatas menunjukan bahwa tingkat efektivitas penerimaan pajak kendaraan bermotor rata-rata dari tahun 2009-2013 adalah sebesar 90,94\%, jika berdasarkan pada kriteria atau indikator tersebut maka penilaiannya adalah efektif. sehingga hal tersebut menunjukan bahwa Dinas Pendapatan dan Pengelolaan Aset Daerah Provinsi Maluku Utara efektif dalam mengelola pajak kendaraan bermotor.

Kontribusi Pajak kendaraan Bermotor terhadap Pendapatan Asli Daerah

Tabel 4.2 dibawah ini akan menggambarkan Kontribusi Pajak Kendaraan bermotor terhadap Pendapatan Asli Daerah (PAD) : 
Tabel 4.2

Kontribusi Pajak atas kendaraan bermotor (PKB) terhadap pendapatan asli daerah (PAD) Pemerintah daerah Provinsi Maluku Utara Tahun 2009-2013

\begin{tabular}{|c|c|c|c|c|}
\hline Tahun & $\begin{array}{c}\text { Realiasi PKB } \\
\text { (Rp) }\end{array}$ & $\begin{array}{c}\text { Realisasi PAD } \\
\text { (Rp) }\end{array}$ & Persentase & Kriteria \\
\hline 2009 & 12.445 .271 .470 & 73.292 .407 .990 & $16,98 \%$ & Kurang \\
\hline 2010 & 13.012 .917 .658 & 76.767 .493 .343 & $16,95 \%$ & Kurang \\
\hline 2011 & 16.181 .204 .891 & 84.811 .587 .801 & $19,07 \%$ & Kurang \\
\hline 2012 & 19.089.343.202 & 115.905.322.982 & $16,47 \%$ & Kurang \\
\hline 2013 & 23.126 .977 .023 & 165.886 .906 .928 & $13,94 \%$ & Kurang \\
\hline \multicolumn{3}{|c|}{ Rata-rata } & $16.68 \%$ & Kurang \\
\hline
\end{tabular}

Sumber : Data diolah, 2014

Tabel 4.2 diatas menunjukan bahwa kontribusi pajak kendaraan bermotor terhadap Pendapatan Asli Daerah rata-rata dari tahun 2009-2013 adalah sebesar 16,68 \%, jika berdasarkan pada kriteria atau indikator tersebut diatas maka penilaiannya adalah kurang baik. Hal tersebut menunjukan bahwa Pemerintah Daerah Provinsi Maluku Utara kurang serius dalam memperhatikan, memanfaatkan, dan mengoptimalkan sumber-sumber penerimaan yang tergolong dalam objek pajak kendaraan bermotor.sehingga kontribusinya terhadap PAD adalah kurang memuaskan.

\section{Pembahasan}

\section{Efektivitas Penerimaan Pajak Kendaraan Bermotor}

Efektivitas Penerimaan Pajak kendaraan bermotor dijelaskan pada gambar 4.1 dibawah ini :

Gambar 4.1

Efektivitas Penerimaan Pajak Kendaraan bermotor Provinsi Maluku Utara tahun 2009-2013

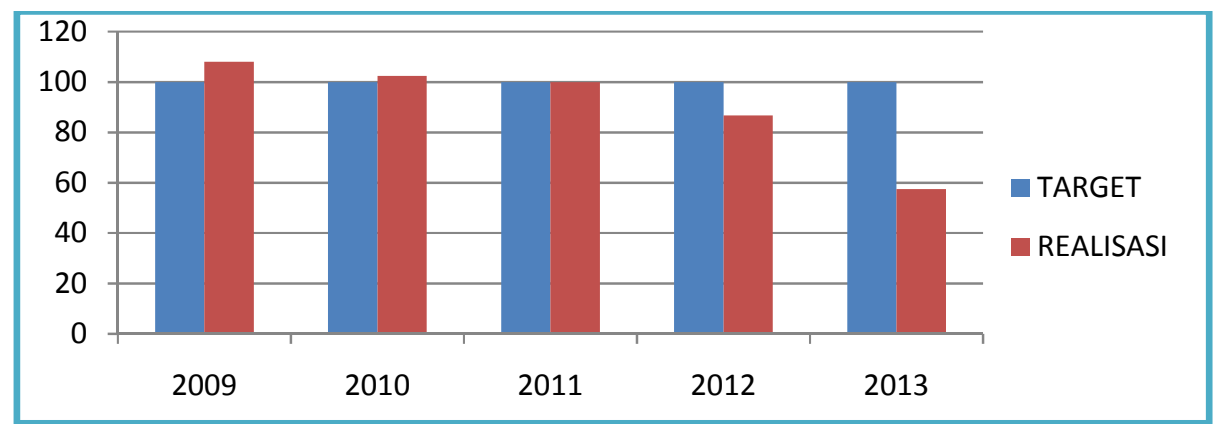

Sumber : Data diolah, 2014

Gambar 4.1 diatas memperlihatkan bahwa tingkat efektivitas penerimaan Pajak atas kendaraan bermotor pada tahun 2009 adalah sebesar 108,10\%, hal tersebut menunjukan bahwa penerimaan pajak kendaraan bemotor pada tahun 2009 adalah sangat efektif. Tahun 2010 adalah sebesar 102,51\%, hal tersebut menunjukan bahwa penerimaan pajak kendaraan bemotor pada tahun 2010 adalah sangat efektif. Tahun 2011 adalah sebesar $100 \%$, hal tersebut menunjukan bahwa penerimaan pajak kendaraan bemotor pada tahun 2011 adalah efektif. Tahun 2012 adalah sebesar 86,74 \%, hal tersebut menunjukan bahwa penerimaan pajak kendaraan bemotor pada tahun 2012 adalah cukup efektif. dan tahun 2013 adalah sebesar 57,37 \%, hal tersebut menunjukan bahwa penerimaan pajak kendaraan bemotor pada tahun 2013 adalah Kurang efektif. Namun jika ditarik secara rata dalam kurun waktu 
2009-2013 adalah sebesar 90,94 \%, yang menunjukan bahwa penerimaan pajak kendaraan bermotor dalam kurun waktu tersebut adalah efektif.

Disisi lain, efektivitas penerimaan pajak atas kendaraan bermotor menunjukan tren yang menurun dari tahun 2009-2013, hal tersebut disebabkan oleh dua faktor, Pertama, terjadinya perbandingan kenaikan antara target dan realisasi pada masing-masing tahun, misalnya kenaikan target pada tahun 2009 ke 2010 adalah sebesar 10,26\%, yang lebih besar dari realisasi sebesar 4,56\%. Target tahun 2010 ke 2011 adalah sebesar 27,47\% lebih besar dari realisasi sebesar 24,35\%. Hal tersebut menggambarkan bahwa efektivitas Pengelolaan pajak kendaraan bermotor oleh Dinas Pendapatan dan pengelolaan Aset Daerah semakin menurun tiap tahunnya, sekalipun data tiap tahunnya menunjukan target penerimaannya tercapai. Akan tetapi secara agregat dari tahun ke tahun menunjukan kenaikan target penerimaan pajak yang naik akibat dipicu oleh peningkatan jumlah kendaraan bermotor akan tetapi tren kenaikan realisasi justru meningkat namun tidak sebanding dengan target penerimaannya.

Kedua, berdasarkan keterangan yang peneliti peroleh dari kepala bidang pajak Dinas Pendapatan dan Pengelolaan Aset Daerah Provinsi Maluku Utara, menyebutkan bahwa dengan dikeluarkannya Peraturan Menteri Energi dan Sumber Daya Mineral no 7 tahun 2012, untuk menindaklanjuti amanat undang-undang no 4 tahun 2009 tentang mineral dan batubara, mengakibatkan sejumlah perusahaan pertambangan dimaluku utara berhenti beroperasi dan menarik alat-alat beratnya dari provinsi maluku utara sehingga terjadi penurunan pencapaian target penerimaan pajak kendaraan bermotor yang bersumber dari alat-alat berat tersebut, bahkan pada tahun 2012 dan 2013 penerimaannya menurun begitu signifikan dibanding dari tahun 2009-2011 bahkan realisasinya tidak mencapai target yang ditetapkan.

\section{Kontribusi Pajak Kendaraan Bermotor terhadap Pendapatan Asli Daerah}

Gambar 4.2 dibawah ini akan menjelaskan kontribusi pajak atas kendaraan bermotor terhadap Pendapatan Asli daerah :

\section{Gambar 4.2 \\ Kontribusi Pajak atas kendaraan bermotor (PKB) terhadap pendapatan asli daerah (PAD) Pemerintah daerah Provinsi Maluku Utara Tahun 2009-2013}

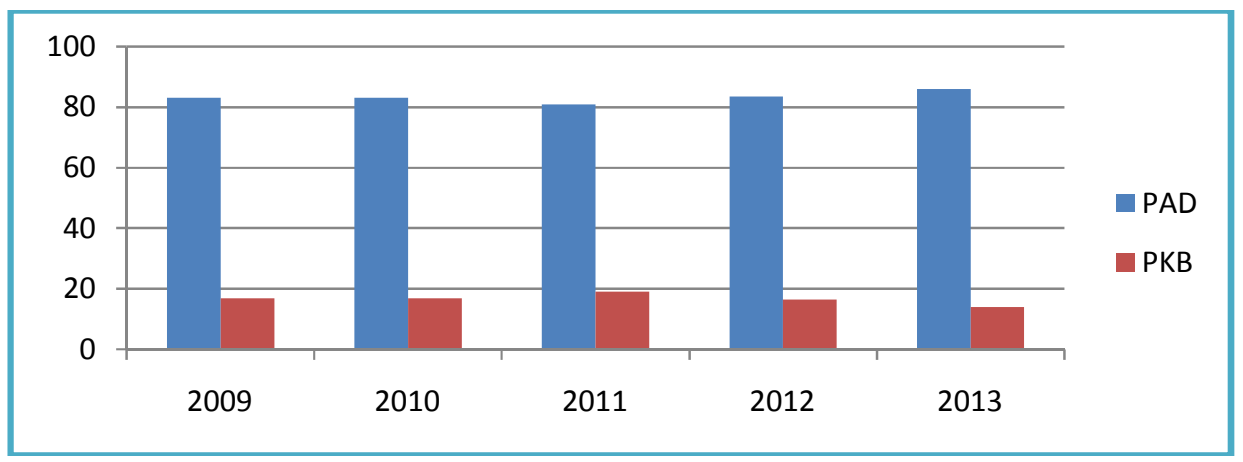

Sumber : Data diolah, 2014

Berdasarkan data yang telah diolah pada Gambar 4.2 menggambarkan antara lain; kontribusi pajak atas kendaraan bermotor terhadap pendapatan asli daerah tahun 2009 adalah sebesar 16,98\%, sementara $83,02 \%$ disumbangkan oleh jenis pajak dan retribusi daerah lainnya. Hal ini menunjukan bahwa persentase kontribusi pajak atas kendaraan bermotor terhadap pendapatan asli daerah pada tahun 2009 adalah kurang baik. Tahun 2010 adalah sebesar 16,95\%, sementara 83,05\% disumbangkan oleh jenis pajak dan retribusi daerah lainnya. Hal ini menunjukan bahwa persentase kontribusi pajak atas kendaraan bermotor terhadap pendapatan asli daerah pada tahun 2010 adalah kurang baik. Tahun 
2011 adalah sebesar 19,07\%, sementara 80,93\% disumbangkan oleh jenis pajak dan retribusi daerah lainnya. Hal ini menunjukan bahwa persentase kontribusi pajak atas kendaraan bermotor terhadap pendapatan asli daerah pada tahun 2011 adalah kurang baik.

Tahun 2012 adalah sebesar 16,47\%, sementara 83,53\% disumbangkan oleh jenis pajak dan retribusi daerah lainnya. Hal ini menunjukan bahwa persentase kontribusi pajak atas kendaraan bermotor terhadap pendapatan asli daerah pada tahun 2012 adalah kurang baik. Tahun 2013 adalah sebesar $13,94 \%$, sementara $86,06 \%$ disumbangkan oleh jenis pajak dan retribusi daerah lainnya. Hal ini menunjukan bahwa persentase kontribusi pajak atas kendaraan bermotor terhadap pendapatan asli daerah pada tahun 2013 adalah kurang baik.

Pada tahun 2009-2013 rata-rata adalah sebesar 16,68\%, sehingga dapat disimpulkan bahwa kontribusi pajak atas kendaraan bermotor terhadap penerimaan Pendapatan asli daerah (PAD) adalah kurang baik. Hal ini menggambarkan bahwa pemerintah daerah provinsi maluku utara kurang serius dalam memperhatikan, memanfaatkan, dan mengoptimalkan sumber-sumber penerimaan yang tergolong dalam objek pajak atas kendaraan bermotor serta faktor-faktor yang lain yang mempengaruhi penerimaan pajak atas kendaraan bermotor.

Disisi lain kontribusi Pajak kendaraan bermotor menunjukan tren yang fluktuatif pada tahun 2011 sementara tahun 2009-2010 dan 2012 ke tahun 2013 adalah menurun. Hal tersebut disebabkan oleh 2 faktor : Pertama, terjadi penurunan efektivitas penerimaan pajak kendaraan bermotor sehingga mengurangi kontribusinya terhadap pendapatan asli daerah,

Kedua, dengan dikeluarkannya Peraturan Menteri Energi dan Sumber Daya Mineral no 7 tahun 2012 untuk menindaklanjuti amanat Undang-undang no 4 tahun 2009 tentang Mineral dan batubara, mengakibatkan sejumlah perusahaan pertambangan dimaluku utara berhenti beroperasi dan menarik alat-alat beratnya dari provinsi maluku utara sehingga terjadi penurunan pencapaian target penerimaan pajak kendaraan bermotor yang bersumber dari alat-alat berat tersebut, bahkan pada tahun 2012 dan 2013 penerimaannya menurun begitu signifikan dibanding dari tahun 2009-2011 bahkan realisasinya tidak mencapai target yang ditetapkan. Sehingga kontribusi pada tahun tersebut menurun begitu pesat.

\section{PENUTUP}

\section{Kesimpulan}

1. Efektifitas penerimaan pajak atas kendaraan bermotor diprovinsi maluku utara adalah efektif. hal ini menunjukan bahwa pemerintah daerah provinsi maluku utara dalam hal ini dinas pendapatan dan pengelola aset daerah dinilai baik/efektif dalam mengelola penerimaan pajak atas kendaraan bermotor, walauapun trend pertumbuhannya dari tahun ke tahun menunjukan kecenderungan menurun akibat dari adanya perbedaan antara kenaikan target dengan realisasinya, serta adanya Peraturan Menteri ESDM tentang pemurnian mineral dan batubara (Minerba) pada tahun 2012, untuk menindaklanjuti UU no 4 tahun 2009 tentang Minerba sehingga Penerimaan pajak kendaraan bermotor yang bersumber dari alat-alat berat berkurang akibat dari tutupnya perusahaan tersebut.

2. Kontribusi pajak atas kendaraan bermotor terhadap penerimaan pendapatan asli daerah diprovinsi Maluku Utara adalah kurang baik hal ini menunjukan bahwa pemerintah daerah Provinsi Maluku Utara dalam hal ini Dinas Pendapatan dan Pengelolaan Aset Daerah Provinsi Maluku Utara kurang serius mengidentifikasi, menggali, dan mengoptimalkan sejumlah objek pajak lainnya yang menjadi objek pajak kendaraan bermotor untuk ditetapkan dan dipungut sebagai pajak atas kendaraan bermotor. sementara trend pertumbuhanya fluktuatif akan tetapi cenderung menurun dari tahun ke tahun, hanya saja pada tahun 2011 mengalami kenaikan dari tahun sebelumnya yang disebabkan oleh menurun tingkat efektivitas penerimaan pajak kendaraan bermotor, serta dengan Peraturan Menteri ESDM no 7 tahun 2012 tentang pemurnian mineral dan batubara (Minerba), untuk menindaklanjuti UU No 4 tahun 2009 tentang Minerba, sehingga mengurangi kontribusi pajak kendaraan bermotor yang bersumber dari alat-alat berat dari perusahaan yang telah berhenti beroperasi akibat dari pemberlakuan undang-undang tersebut.

\section{Saran}


1. Karena kontribusi pajak atas kendaraan bermotor terhadap pendapatan asli daerah kurang baik maka penulis merekomendasikan kepada Pemerintah Daerah Provinsi Maluku Utara dalam hal ini Dinas Pendapatan dan Pengelolaan Aset Daerah (DPPAD) Provinsi Maluku Utara untuk lebih meningkatkan potensi penerimaan pajak atas kendaraan bermotor dengan cara mengindetifikasi objek pajak yang terkait dengan pajak kendaraan bermotor yang masih belum teridentifikasi untuk dikenakan pungutan sehingga penerimaan pajak atas kendaraan dapat menjadi optimal. Serta melakukan sejumlah langkah berupa sosialisasi tentang pentingnya pajak bagi keberlangsungan pembangunan infrasturuktur jalan serta pendukung lainnya sebagai penunjang berkendara.

2. Memberikan rekomendasi kepada UPTD SAMSAT disetiap kabupaten/kota yang ada diprovinsi maluku utara untuk meningkatkan tingkat pelayanan, khususnya kemudahan dalam membayar pajak atas kendaraan bermotor sehingga penerimaan pajak atas kendaraan bermotor lebih optimal dan dapat meningkat. Serta adanya tindakan tegas, dalam hal ini bekerja sama dengan pihak kepolisian guna melakukan penertiban terhadap kendaraan bermotor yang melakukan tunggakan pajak.

\section{DAFTAR PUSTAKA}

Adelina, Rima. 2012. Analisis Efektifitas dan Kontribusi Penerimaan Pajak Bumi dan Bangunan (PBB) terhadap Pendapatan Daerah diKabupaten Gresik. Universitas Negeri Surabaya. Skripsi

Guritno, T. 1997. Kamus Ekonomi-binis-perbankan : Inggris-Indonesia. Gajah Mada University Press. Yogyakarta.

Halim, Abdul. 2007. Akuntansi Keuangan Daerah. Salemba Empat. Jakarta.

Mardiasmo. 2008. Perpajakan, Andi. Yogyakarta.

Mardiasmo. 2009. Akuntansi Sektor Publik. Andi. Yogyakarta.

Resmi, Siti. 2009. Perpajakan Teori dan Kasus, Buku 1 edisi 5. Salemba Empat. Jakarta.

Sugiono. 2008a. Mamahami Penelitian Kualitatif, Cv Alfabeta. Bandung.

Sugiono. 2008b. Statistika Untuk Penelitian. Cv Alfabeta. Bandung.

Tarigan, K Wanta. 2013. Jurnal Emba ISSN 2303-1174 Vol.1 3 juni 2013,hal 282-291. Analisis Efektivitas dan kontribusi PBB terhadap Penerimaan Pajak Di KPP Pramata Manado. Universitas Sam Ratulangi.

Velayati, M Rizkika, Dkk. 2013. Analisis efektivitas dan kontribusi tindakan penagihan pajak aktif dengan surat teguran dan surat paksa sebagai upaya pencairan tunggakan pajak. Studi pada kantor pelayanan pajak pratama batu tahun 2010-2012. Universitas Brawijaya. Skripsi.

Waluyo. 2009. Perpajakan Indonesia, buku 1 Edisi 9. Salemba Empat. Jakarta

Waluyo. 2012. Akuntansi Pajak, Edisi 4. Salemba Empat. Jakarta

Daerah.

Undang-undang Republik Indonesia No 28 tahun 2009 tentang pajak daerah dan Retribusi

Undang-Undang Republik Indonesia No. 12 tahun 2008 tentang Pemerintah Daerah.

Undang-Undang Republik Indonesia No. 33 Tahun 2004 tentang Hubungan Perimbangan

Keuangan Antara Pemerintah Pusat dan Pemerintah Daerah.

Undang-Undang Republik Indonesia No. 9 Tahun 2009 tentang Mineral dan Batubara

Peraturan Menteri Energi dan Sumber Daya Mineral No 7 Tahun 2012 tentang Peningkatan

Nilai Mineral Melalui Kegiatan Pengolahan dan Pemurnian.

Peraturan Daerah Provinsi Maluku Utara No Tahun 2012 tentang Pajak Daerah.

Buku Profil Dirjen Pehubungan Darat 2013. www.ditjenhubdat.kemenhub.go.id 